\title{
Ordforklaringer
}

Cerebral parese defineres som bevegelsesforstyrrelser som skyldes utviklingsfeil eller skade i hjernen - oppstått $\mathrm{i}$ fosterlivet eller de første levemånedene.

Apgarskår er et system for å registrere vitalitet hos et nyfødt barn, basert på bedømmelse av hjerteaktivitet, respirasjon, hudfarge (frisk eller blåblek), muskelspenning og reaksjonsevne. Apgarskår på sju-ti regnes som normalt, fire-seks som lavt, og under fire som svært lavt. Testen har sitt navn etter den amerikanske legen Virginia Apgar (1909-74) som introduserte testen i 1953.

\section{Lav apgarskår forbundet med cerebral parese}

\author{
Barn med lav apgarskår har økt risiko for cerebral parese, men selv \\ etter svært lav apgarskår er det 80-90 \% som ikke utvikler sykdommen. \\ Det viser ny norsk forskning.
}

Cerebral parese forekommer hos ca. to per 1000 barn i vestlige land. Årsaken er i de fleste tilfellene ukjent. Tidligere er det vist en sterk sammenheng mellom apgarskår og cerebral parese hos fullbårne barn. Hvorvidt det finnes en slik sammenheng hos barn med lav fødselsvekt har vært uklart, blant annet fordi premature barn har økt forekomst både av lav apgarskår og cerebral parese. Nå har norske forskere undersøkt dette (1).

- I denne undersøkelsen har vi benyttet et forskningsregister over barn med cerebral parese født i perioden 1986-95. Registeret er koblet til medisinsk fødselsregister. Av 543064 barn som inngikk i studien, hadde 988 fått diagnosen cerebral parese. Vi undersøkte sammenhengen mellom apgarskår fem minutter etter fødselen, fødselsvekt og cerebral parese, sier førsteforfatter Kari Kveim Lie ved Nasjonalt folkehelseinstitutt.

- Barna ble delt inn i tre fødselsvektgrupper. I alle gruppene var det en betydelig forskjell på forekomst av cerebral parese hos barn med normal apgarskår og barn med lav apgarskår. Hos barn med normal fødselsvekt ( $\geq 2500 \mathrm{~g}$ ) og apgarskår $>8$ var det bare $0,1 \%$ som fikk cerebral parese, mens hele $10 \%$ av barna med apgarskår $<4$ utviklet cerebral parese. Også hos barn med fødselsvekt $<1500 \mathrm{~g}$ var det forskjell i risiko for cerebral parese, avhengig av apgarskår ( $4 \%$ versus $17 \%$ ved henholdsvis apgarskår $>8$ og $<4)$.

Tidligere trodde man at de fleste tilfellene av cerebral parese skyldtes hypoksi og hjerneskade i forbindelse med fødselen, mens nyere forskning tyder på at prenatal årsak er dominerende. Problemstillingen prenatal eller perinatal skade er av og til aktuell i erstatningssøksmål knyttet til funksjonshemmede barn. Vår undersøkelse kan imidlertid ikke belyse dette spørsmålet. Lav apgarskår kan skyldes fødselsrelatert hypoksi, men kan like gjerne være uttrykk for en hjerneskade som er oppstått prenatalt - den samme som senere gir cerebral parese, forteller Kari Kveim Lie.

Dette understrekes i en lederartikkel, hvor man også blir påmint om at godt klinisk skjønn, her uttrykt i apgarskår, ikke blir avleggs, selv i en tidsalder der avansert teknologisk utstyr får stadig større utbredelse (2).

- Det er viktig å kjenne til at barn med lav apgarskår har økt risiko for cerebral parese, og like viktig at selv etter svært lav apgarskår var det 80-90 \% som ikke utviklet cerebral parese, sier Kari Kveim Lie, som har skrevet artikkelen sammen med Else-Karin Grøholt og Anne Eskild.

\section{Registerforskning \\ av cerebral parese}

Kari Kveim Lie og Else-Karin Grøholt er forskere ved Divisjon for epidemiologi, Nasjonalt folkehelseinstitutt. Anne Eskild er professor ved Avdeling for obstetrikk og gynekologi ved Akershus universitetssykehus og har en bistilling ved Divisjon for psykisk helse ved Folkehelseinstituttet. Stiftelsen Helse og rehabilitering finansierte etablering av et forskningsregister over barn med cerebral parese født 1986-95.

\section{Erlend Hem}

erlend.hem@medisin.uio.no

Tidsskriftet

\section{Litteratur}

1. Lie KK, Grøholt E-K, Eskild A. Association of cerebral palsy with Apgar score in low and normal birthweight infants: population based cohort study. BMJ 2010; 341: c4990.

2. Paneth N. Apgar score and risk of cerebral palsy. BMJ 2010: 341: c5175.

\section{$\underline{\mathrm{BMJ}}$}

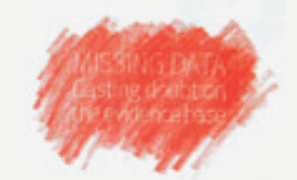

Artikkelen ble e-publisert 7.10.2010 i BMJ (www.bmj.com), som regnes som en av de «fem store» innen medisinsk publisering ved siden av New England Journal of Medicine, JAMA, Annals of Internal Medicine og The Lancet

\section{Tips oss}

Er du iferd med å publisere eller har du nylig publisert et internasjonalt tidsskrift? erlend.hem@medisin.uio.no 